\title{
A new species of Echinoderes from Florida (Kinorhyncha: Cyclorhagida) Cyclorhagida)
}

Sørensen, Martin V.; Heiner, Iben; Ziemer, Ole

Published in:

Proceedings of the Biological Society of Washington

DOI:

10.2988/0006-324X(2005)118[499:ANSOEF]2.0.CO;2

Publication date:

2005

Document version

Publisher's PDF, also known as Version of record

Citation for published version (APA):

Sørensen, M. V., Heiner, I., \& Ziemer, O. (2005). A new species of Echinoderes from Florida (Kinorhyncha: Cyclorhagida): Cyclorhagida). Proceedings of the Biological Society of Washington, 118(3), 499-508. https://doi.org/10.2988/0006-324X(2005)118[499:ANSOEF]2.0.CO;2 


\title{
A new species of Echinoderes from Florida (Kinorhyncha: Cyclorhagida)
}

Authors: Sørensen, Martin V., Heiner, Iben, and Ziemer, Ole Source: Proceedings of the Biological Society of Washington, 118(3) : 499-508

\author{
Published By: Biological Society of Washington
}

URL: https://doi.org/10.2988/0006324X(2005)118[499:ANSOEF]2.0.CO;2

BioOne Complete (complete.BioOne.org) is a full-text database of 200 subscribed and open-access titles in the biological, ecological, and environmental sciences published by nonprofit societies, associations, museums, institutions, and presses.

Your use of this PDF, the BioOne Complete website, and all posted and associated content indicates your acceptance of BioOne's Terms of Use, available at www.bioone.org/terms-of-use.

Usage of BioOne Complete content is strictly limited to personal, educational, and non - commercial use. Commercial inquiries or rights and permissions requests should be directed to the individual publisher as copyright holder.

BioOne sees sustainable scholarly publishing as an inherently collaborative enterprise connecting authors, nonprofit publishers, academic institutions, research libraries, and research funders in the common goal of maximizing access to critical research. 


\title{
A new species of Echinoderes from Florida (Kinorhyncha: Cyclorhagida)
}

\author{
Martin V. Sørensen, Iben Heiner, and Ole Ziemer \\ (MVS) Department of Geophysics, University of Copenhagen, Juliane Maries Vej 30, \\ 2100 Copenhagen, Denmark, e-mail: mvsorensen@bi.ku.dk; \\ (OZ and IH) Zoological Museum, University of Copenhagen, Universitetsparken 15, \\ 2100 Copenhagen, Denmark
}

Abstract.-A new kinorhynch, Echinoderes spinifurca, is described from the Atlantic coast off Fort Pierce, Florida. The species is characterized by the presence of middorsal spines on segments 6 to 10 and lateral spines/tubules on segments 4 and $7-12$. The tergal furca (tergal extension) is extraordinarily long, constituting 9.3-12.9 percent of the trunk length, and this distinct character makes it easy to distinguish the species from all other species of Echinoderes. Echinoderes spinifurca occurs in shell gravel and mixed shell gravel with sand, and coexists with Echinoderes horni, Zelinkaderes sp., and two undescribed cyclorhagid taxa.

With 63 valid species, Echinoderes is by far the largest kinorhynch genus. The genus is characterized by the presence of 16 scalids in the neck closing apparatus, and a midventral placid that is always twice as wide as the others. The two first trunk zonites, segment 3 and 4 , consist of complete cuticular rings, whereas the following segments are composed of a tergal and two sternal plates. Middorsal spines are present in many species, and lateral terminal spines are always present as well. Contrarily, a midterminal spine is never present in species of the genus. Echinoderes can hardly be confused with any other genus, except Cephalorhyncha, which superficially may have the same appearance. However, segment 4 in Cephalorhyncha is composed of a sternal and two partly fused ventral plates, contrary to the condition in species of Echinoderes (see Adrianov \& Malakhov 1999).

The genus Echinoderes appears to be cosmopolitan, and has been recorded from various habitats and sediment types ranging from black mud to shell gravel and clean coral sand, but also associated with kelp holdfasts, calcareous algae, or the rare min- eral ikaite (see, e.g., Higgins 1983, 1985, 1986a; Higgins \& Kristensen 1988; Sørensen \& Kristensen 2000; Adrianov et al. 2002). This study presents parts of the results from meiofauna collections from shell gravel and sand mixed with shells in the Atlantic Ocean off Fort Pierce, Florida, taken during a stay at the Smithsonian Marine Station at Fort Pierce.

\section{Materials and Methods}

The samples were taken at $15.1 \mathrm{~m}$ depth with a meiofauna dredge from the research vessel R/V Sunburst at a locality off Fort Pierce, Florida. The meiofauna was extracted with freshwater shocking (Kristensen \& Higgins 1984) followed by decantation through a $30 \mu \mathrm{m}$ net. The concentrate was fixed in $4 \%$ formalin buffered with borax. Subsequently the kinorhynchs were sorted out under an Olympus ZX12 dissecting microscope. Specimens for light microscopy were dehydrated through a graded series of glycerin and mounted in Fluoromount $\mathrm{G}^{\circledR}$. The mounted specimens were examined and photographed using Nomarski differ- 
ential interference contrast with an Olympus BX60 microscope equipped with an Olympus DP10 digital camera. Measurements were made with Olympus DP-Soft software for analysis of light microscopical photos. Drawings were made with a camera lucida. Specimens for SEM were dehydrated through a graded series of ethanol, transferred to acetone, and critical point dried. The dried specimens were mounted on aluminum stubs, sputter coated, and examined with a JEOL JSM-6335F field emission scanning electron microscope.

Type material is deposited in the Zoological Museum, University of Copenhagen (ZMUC), Denmark.

\section{Description}

Phylum Kinorhyncha Dujardin, 1851 Order Cyclorhagae Zelinka, 1896

Family Echinoderidae Bütschli, 1876

Genus Echinoderes Claparède, 1863

Echinoderes spinifurca, new species Figs. 1-4

Material examined.-Holotype adult female KIN-122 (Fig. 1A), collected 22 Jul 2003 , at $29^{\circ} 29.558^{\prime} \mathrm{N}, 80^{\circ} 12.233^{\prime} \mathrm{W}$, off Fort Pierce, Florida, mounted in Fluoromount $\mathrm{G}^{\circledR}$, deposited in the Zoological Museum, University of Copenhagen (ZMUC), Denmark. Allotype adult male KIN-123 (Fig. 1B), collected at same date and location as holotype, mounted in Fluoromount $\mathrm{G}^{\circledR}$, deposited in the Zoological Museum, University of Copenhagen (ZMUC), Denmark. Paratypes 5 females and 5 males, KIN-124-KIN-133, collected at same date and location as holotype, mounted in Fluoromount $G^{\circledR}$, deposited in the Zoological Museum, University of Copenhagen (ZMUC), Denmark.

Diagnosis. - Middorsal spines on segments 6-10, increasing in length posteriorly; ventrolateral tubules on segment 4; lateroventral tubules on segment 7; lateroventral spines on segments $8-11$; laterodorsal tubules on segments 12; lateral terminal spines long, 171-191 $\mu \mathrm{m}, 59.9-78.9$ per- cent of trunk length. Tergal furca, or tergal extension, very long, 26-32 $\mu \mathrm{m}, 9.3-11.9$ percent of trunk length, acicular, with strong pectinate fringes on inferior margin of bases.

Description.-Second segment with 16 placids, about $11 \mu \mathrm{m}$ long, $5 \mu \mathrm{m}$ wide posteriorly, more narrow anteriorly; midventral placid wider, $9 \mu \mathrm{m}$ at base (Fig. 2A, B). Anterior margin of midventral placid with small heart-shaped plate overhanging anterior margin. Ventral trichoscalid plates large, $10 \mu \mathrm{m}$ wide at expanded portion of overlapping placid; dorsal trichoscalid plates smaller, $6 \mu \mathrm{m}$ at bases (Fig. 2B).

Segment 3 consists of one complete cuticular ring. One middorsal glandular pore and pair of subdorsal, laterodorsal, and ventrolateral sensory spots are located near anterior margin of segment; dorsal perforation sites evenly scattered, ventral perforation sites a single row; pectinate fringe uniform at posterior margin of entire segment (Fig. 2A, B).

Segment 4 consists of one complete cuticular ring. Dorsal side with one middorsal glandular pore (Fig. 4A) and one pair of laterodorsal sensory spots; ventral side with one pair of ventrolateral tubules (VL4), one pair of ventrolateral sensory spots located close to VL4 (Figs. 3C, 4B), and one pair of ventromedial cuticular scars located closer to the anterior margin. Perforation sites on dorsal side evenly distributed, ventral perforation sites in one row posterior on segment and scattered anterior to the row; pectinate fringe uniform at posterior margin of entire segment.

Segment 5 and following segments consist of one tergal plate and two sternal plates (Fig. 3B); lateral tergal-sternal junctions are indistinct, whereas the midventral junction is more conspicuous (Figs. 1A, 4B, D). Dorsal side with one middorsal glandular pore and one pair of paradorsal sensory spots; lateral and ventral sides with one pair of lateral sensory spots and one pair of ventromedial glandular pores. Perforation sites and pectinate fringe like segment 4 . 


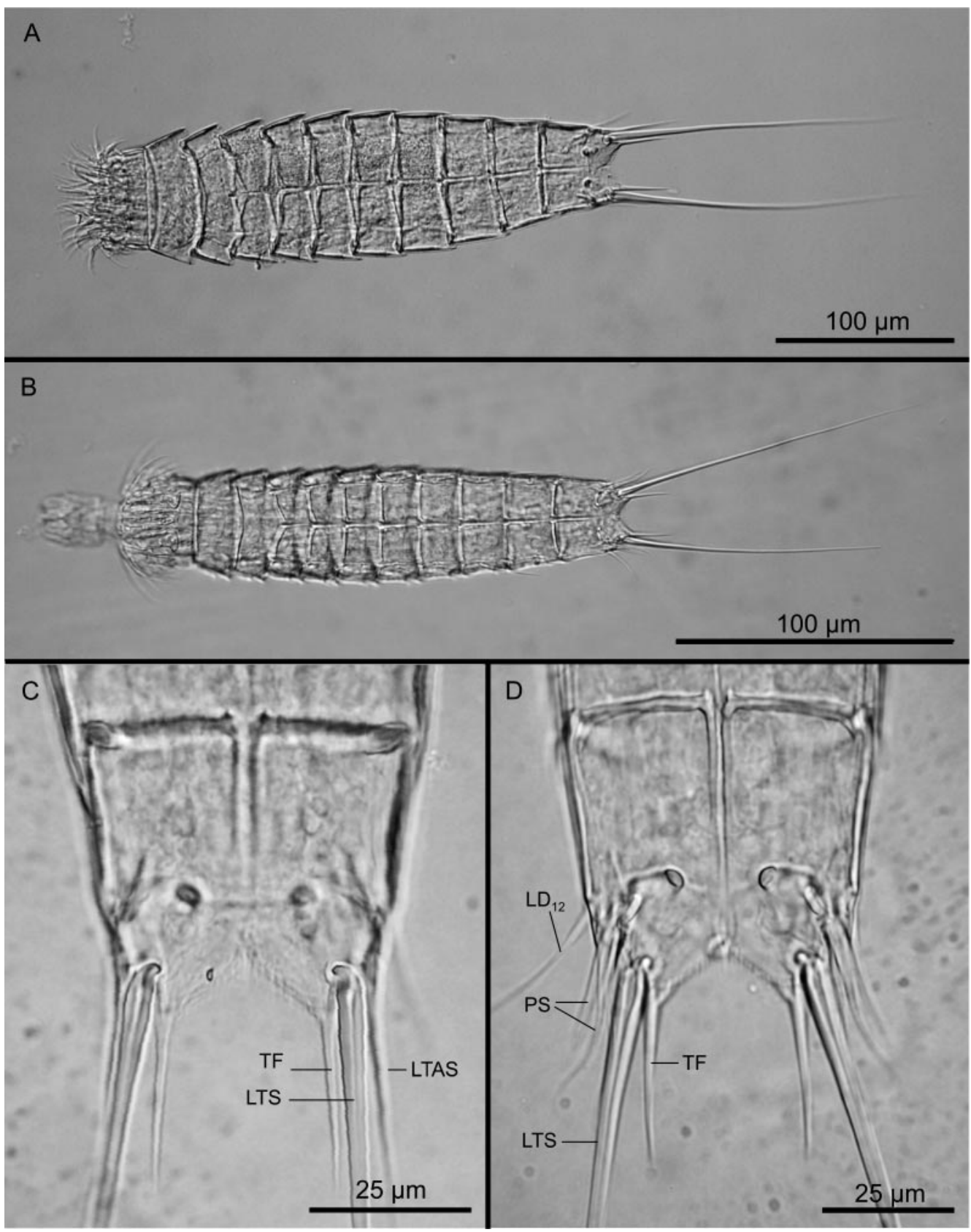

Fig. 1. Light micrographs of female holotype and male allotype of Echinoderes spinifurca. A, Female holotype, ventral view. B, Male allotype, ventral view. C, Female holotype, segments 12-13, dorsal view. D, Male allotype, segments 12-13, ventral view. Abbreviations; LD, laterodorsal tubule; LTAS, lateral terminal accessory spine; LTS, lateral terminal spine; PS, penile spine; TF, tergal furca. 


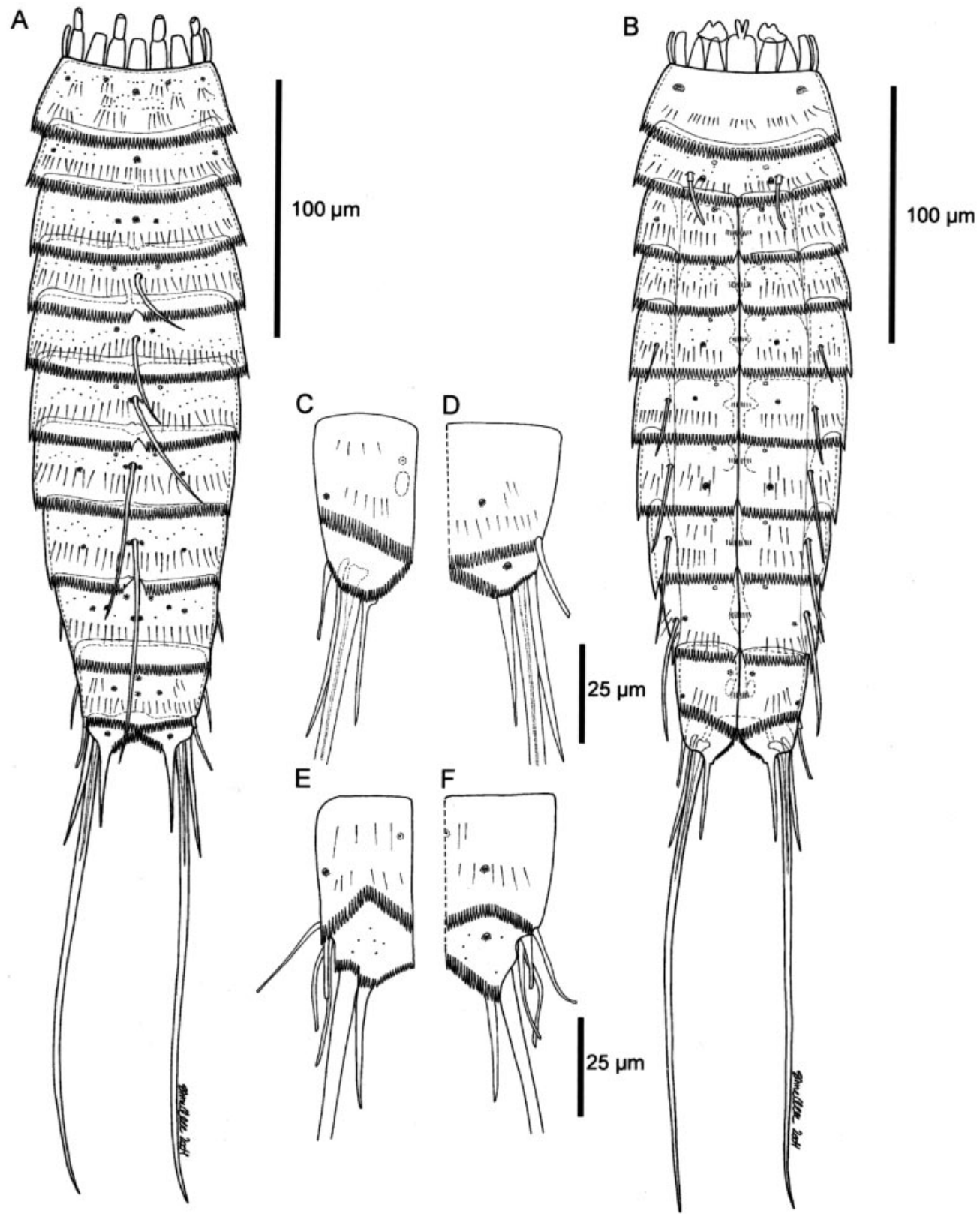

Fig. 2. Echinoderes spinifurca. A. Female, dorsal view. B. Female, ventral view. C. Female, left part of segments 12-13, ventral view. D. Female, right part of segments 12-13, dorsal view. E. Male, left part of segments $12-13$, ventral view. F. Male, right part of segments $12-13$, dorsal view.

Segment 6 with well developed pachycycli. Dorsal side with one middorsal spine, and one pair of paradorsal glandular openings, located close to the anterior margin of segment; ventral side with one pair of in- conspicuous ventromedial cuticular scars, located close to anterior margin of segment (Fig. 4C); perforation sites and pectinate fringe like segment 5 .

Segment 7 with one middorsal spine 

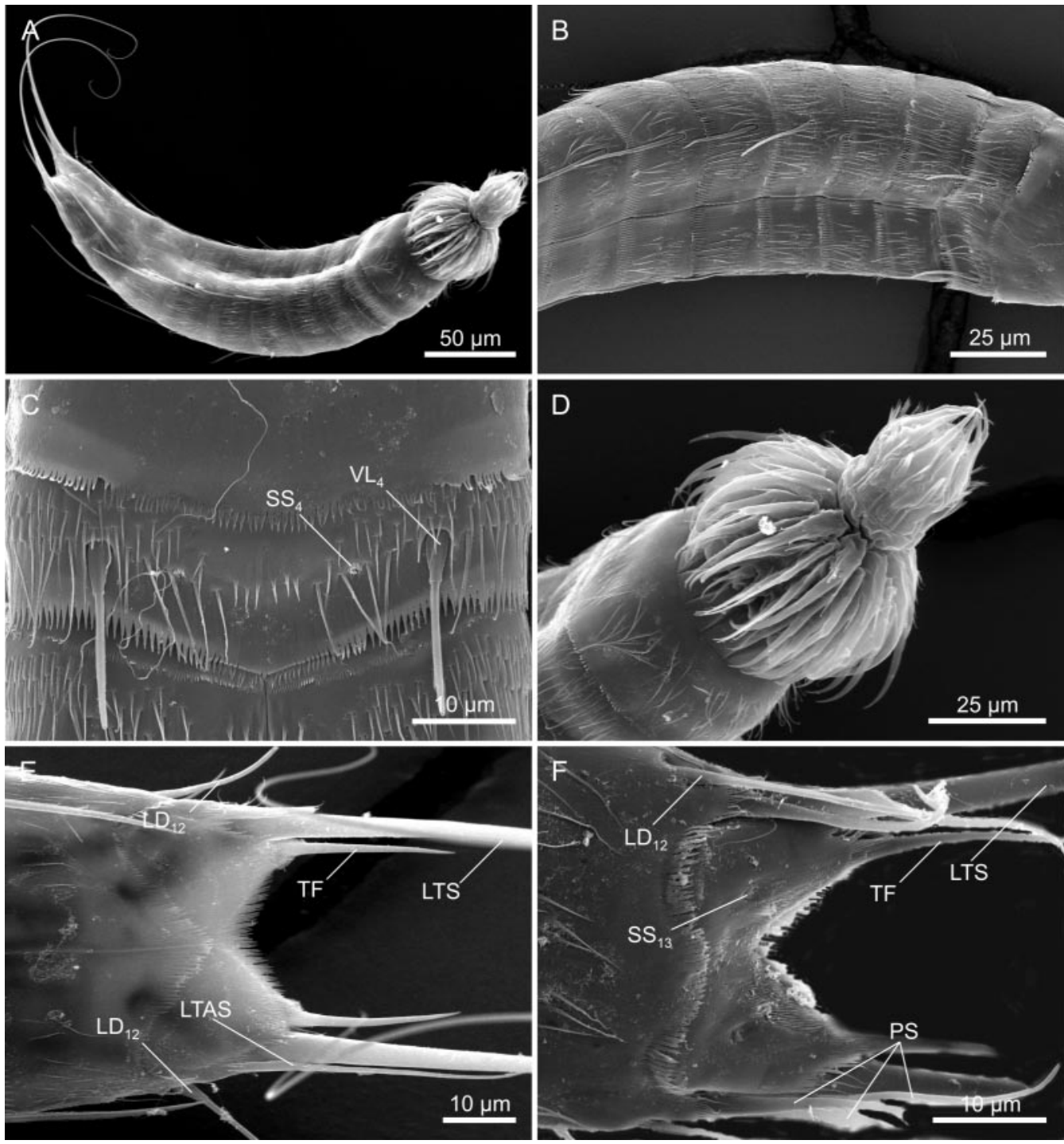

Fig. 3. Scanning electron micrographs of Echinoderes spinifurca. A, Female, lateroventral view. B, Female, segments 3-10, ventral view. C, Female, segment 4, ventral view. D, Female, head, neck and segment 3, lateral view. E, Female, segments 12-13, ventral view. F, Male, segments 12-13, dorsal view. Abbreviations: LD, laterodorsal tubule; LTAS, lateral terminal accessory spine; LTS, lateral terminal spine; PS, penile spine; SS, sensory spot; TF, tergal furca; VL, ventrolateral tubule.

(MD7), and one pair of paradorsal sensory spots, located close to the anterior margin of segment; ventral side with one pair of short lateroventral tubules (LV7), one pair of ventromedial cuticular scars, located close to the anterior margin, and one pair ventromedial sensory spots, located more mesially on segment. Segment otherwise like segment 6 .
Segment 8 with one middorsal spine (MD8), flanked by pair of inconspicuous sensory spots; one pair of paradorsal cuticular scars is located closer to the anterior margin of segment; ventral side with one pair of short lateroventral acicular spines (LV8), one pair of ventromedial cuticular scars, located close to the anterior margin, and one pair ventromedial sensory spots, 

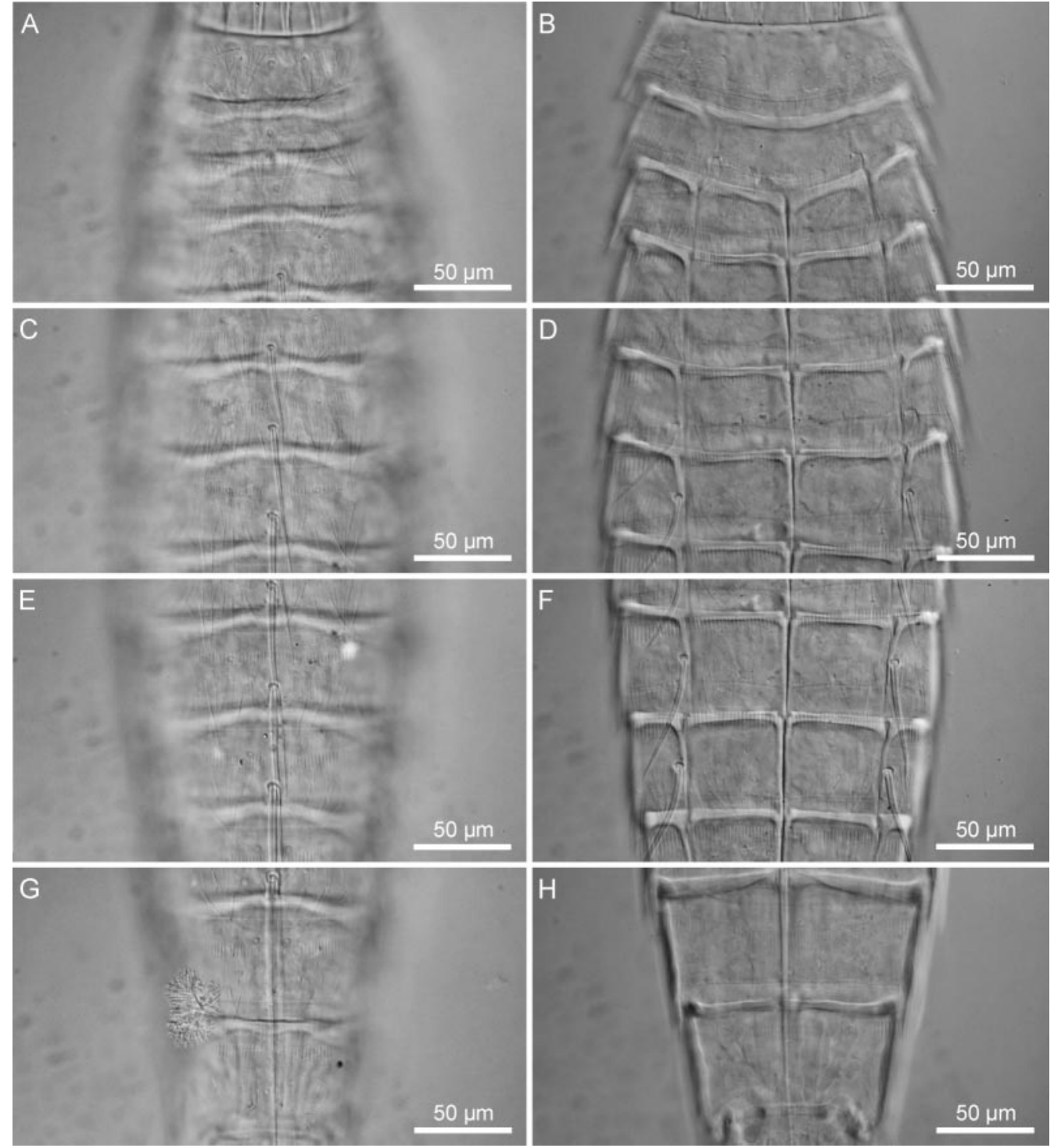

Fig. 4. Light micrographs of male paratypes of Echinoderes spinifurca. Left column displays dorsal view, right column ventral view. A-B, Segments 3 to 6. C-D, Segments 6 to 8. E-F, Segments 9 and 10. G-H, Segments 11 and 12 .

located more mesially on segment. Segment otherwise like segment 7.

Segment 9 with middorsal spine (MD9), flanked by pair of inconspicuous sensory spots; one pair of subdorsal sensory spots is present mesially, and one pair of paradorsal cuticular scars is located closer to the anterior margin of segment; ventral side with one pair of short lateroventral acicular spines (LV9), one pair of ventromedial cuticular scars, located close to the anterior margin, and one pair ventromedial sensory spots, located more mesially on segment. Segment otherwise like segment 8 .

Segment 10 with middorsal spine (MD10), flanked by pair of inconspicuous sensory spots; one pair of subdorsal sensory spots is present mesially, paradorsal cutic- 
Table 1.-Measurements (in $\mu \mathrm{m}$ ) of adult Echinoderes spinifurca, including number of measured specimens $(n)$ and standard deviation $(S D)$. Abbreviations: LTS: lateral terminal spine; MSW: maximum sternal width; SW: standard width; S2-13: segment lengths of segments 2-13; TF: tergal furca; TL: trunk length.

\begin{tabular}{lcccr}
\hline Character & $n$ & Range & Mean & $S D$ \\
\hline TL & 12 & $232-301$ & 269.7 & 20.9 \\
SW & 12 & $40-47$ & 42.9 & 2.3 \\
SW/TL & 12 & $14.0-18.1$ & 16.0 & 1.4 \\
MSW-7 & 12 & $45-53$ & 49.4 & 2.6 \\
MSW/TL & 12 & $16.5-20.9$ & 18.4 & 1.5 \\
LTS/TL & 12 & $59.9-78.9$ & 67.8 & 6.0 \\
TF/TL & 12 & $9.3-11.9$ & 10.6 & 0.8 \\
S2 & 12 & $9-14$ & 11.3 & 1.3 \\
S3 & 12 & $22-34$ & 26.9 & 3.3 \\
S4 & 12 & $17-29$ & 23.1 & 2.8 \\
S5 & 12 & $18-24$ & 20.8 & 1.9 \\
S6 & 12 & $19-27$ & 22.8 & 2.2 \\
S7 & 12 & $22-26$ & 23.6 & 1.3 \\
S8 & 12 & $23-28$ & 25.7 & 1.6 \\
S9 & 12 & $24-31$ & 27.3 & 2.3 \\
S10 & 12 & $23-32$ & 28.6 & 2.9 \\
S11 & 12 & $26-34$ & 31.1 & 2.6 \\
S12 & 12 & $22-33$ & 28.5 & 2.8 \\
S13 & 12 & $42-51$ & 47.2 & 2.9 \\
\hline
\end{tabular}

ular scars absent; ventral side with one pair of short lateroventral acicular spines (LV10), one pair of ventromedial cuticular scars, located close to the anterior margin, ventromedial sensory spots absent. Segment otherwise like segment 9.

Segment 11 without middorsal spine; with one pair of paradorsal glandular pores near anterior margin of segment (Fig. 4G), one pair of paradorsal and two pairs of subdorsal sensory spots are present more mesially; ventral side with one pair of lateroventral acicular spines (LV11), one pair of ventromedial cuticular scars, located close to the anterior margin, and one pair of ventrolateral sensory spots more mesially. Protonephridial sieve plate located in a laterodorsal position; perforation sites on ventral side mostly on posterior part of segment; segment otherwise like segment 10 .

Segment 12 with two middorsal glandular pores, one pair of subdorsal sensory spots, and one pair of laterodorsal tubules (LD12), situated posteriorly on segment
Table 2.-Spine/tubule measurements (in $\mu \mathrm{m}$ ) of adult Echinoderes spinifurca, including number of measured specimens $(n)$ and standard deviation $(S D)$. Abbreviations: LD: laterodorsal tubule; LTAS: lateral terminal accessory spine; LTS: lateral terminal spine; LV: lateroventral; MD: middorsal; TF: tergal furca; VL: ventrolateral.

\begin{tabular}{lrrrr}
\hline Character & $n$ & Range & Mean & $S D$ \\
\hline VL 4 & 12 & $17-23$ & 20.4 & 1.7 \\
LV 7 & 12 & $10-28$ & 22.5 & 4.7 \\
LV 8 & 12 & $18-23$ & 21.0 & 1.5 \\
LV 9 & 12 & $29-35$ & 32.0 & 2.1 \\
LV 10 & 12 & $33-43$ & 38.7 & 2.9 \\
LV 11 & 12 & $36-46$ & 42.2 & 4.1 \\
LD 12 & 12 & $22-30$ & 24.8 & 2.1 \\
MD 6 & 10 & $21-29$ & 25.0 & 2.6 \\
MD 7 & 11 & $28-38$ & 33.6 & 3.0 \\
MD 8 & 11 & $43-55$ & 49.1 & 3.6 \\
MD 9 & 12 & $49-63$ & 57.0 & 4.3 \\
MD 10 & 12 & $70-88$ & 75.4 & 5.8 \\
TF & 12 & $26-32$ & 28.3 & 1.8 \\
LTAS & 6 & $39-53$ & 46.8 & 5.2 \\
LTS & 12 & $171-191$ & 181.6 & 7.5 \\
\hline
\end{tabular}

(Figs. 1D, 2, 3E, F); ventral side with one pair of ventrolateral sensory spots and one pair of ventromedial glandular pores, one prominent pair of ventromedial muscle scars is present posterior to glandular pores. Perforation sites like segment 11, pectinate fringe of sternal plates medially extending beyond posterior margin of segment 13 (Fig. 3E).

Segment 13 with one pair of subdorsal sensory spots (Fig. 3F); lateral terminal spines (LTS) long; tergal furca very elongate with spinous extensions, inferior margins of bases on tergal furca with well-developed dorsal pectinate fringe; females with pair of lateral accessory terminal spines (LTAS); males with three pairs of penile spines (Figs. 1C-F, 2C, D, 3E, F).

Size and dimensions of spines and segments are summarized in Tables 1 and 2 . The sizes or dimensions do not differ between the sexes. The positions of spines, sensory spots and glandular pores are summarized in Table 3.

Etymology.-The name spinifurca is 
Table 3.- Summary of nature and location of sensory spots, pores, muscle scars, spines, and tubules arranged by series in Echinoderes spinifurca. Abbreviations: LA: lateral accessory; LD: laterodorsal; LTAS: lateral terminal accessory spine; LTS: lateral terminal spine; LV: lateroventral; MD: middorsal; PD: paradorsal; SD: subdorsal; SL: sublateral; VL: ventrolateral; VM: ventromedial. ac: acicular spine; cs: cuticular scar; F: only present in females; gp: glandular pore; ms: muscle scar; ss: sensory spot; tu: tubule.

\begin{tabular}{lccccccccccc}
\hline \multicolumn{1}{c}{ Segment } & 3 & 4 & 5 & 6 & 7 & 8 & 9 & 10 & 11 & 12 & 13 \\
\hline MD & gp & & gp & ac & ac & ac & ac & ac & & gp, gp & \\
PD & & & ss & gp & ss & cs, ss & cs, ss & ss & gp, ss & & \\
SD & ss & & & & & & ss & ss & ss, ss & ss & ss \\
LD & ss & ss & & & & & & & & tu & \\
SL & & & & & & & & & & & \\
LA (incl. LTAS) & & & ss & & & & & & & & ac (F) \\
LV (incl. LTS) & & & & & tu & ac & ac & ac & ac & & ac \\
VL & ss & tu, ss & & & & & & & ss & ss & \\
VM & & cs & gp & cs & cs, ss & cs, ss & cs, ss & cs & cs & gp, ms & \\
\hline
\end{tabular}

from Latin and refers to the very long and spine-like tergal furca.

Notes on diagnostic features and systematic position.-Based on the combination of the present spine formula and the conspicuously long tergal furca (Figs. 1C, D, 2, 3A, E, F) Echinoderes spinifurca cannot be confused with any other species. The tergal furca constitutes about 10.6 percent of the total trunk length, which exceeds the ratios in any other species with relatively long tergal furca, including E. arlis Higgins, 1966 a $($ furca/TL $\approx 5.9), E$. andamanensis Higgins \& Rao, 1979 (furca/TL $\approx$ 8.3), E. bermudensis Higgins, 1982 (furca/ $\mathrm{TL} \approx 7.8$ ), and E. filispinosus Adrianov, 1989 (furca/TL $\approx 7.3$ ). Echinoderes spinifurca is furthermore the only one of the above mentioned species that possesses five middorsal spines, and is therefore easily recognized. Only E. higginsi Huys \& Coomans, 1989 has a furca/TL ratio (furca/TL $\approx 10.5$ ) that exceeds the ratio in $E$. spinifurca, but $E$. higginsi has middorsal spines on only segments 6,8 , and 10 and a long lateral accessory spine on segment 10 , so the two species are easily distinguished by the different spine formulas.

The spine formula in Echinoderes spinifurca is identical with the formula in thirteen other Echinoderes species: E. aureus Adrianov et al., 2002, E. brevicaudatus Higgins, 1966b, E. dujardinii Claparède,
1863, E. ehlersi, Zelinka, 1913, E. ferrugineus Zelinka, 1928, E. imperforatus Higgins, 1983, E. kozloffi Higgins, 1977a, E. krishnaswamyi Higgins, 1985, E. nybakkeni Higgins, 1986a, E. pacificus Schmidt, 1974, E. pilosus Lang, 1949, E. sublicarum Higgins, 1977b, and E. worthingi Southern, 1914. Echinoderes spinifurca can easily be discriminated from these by the shape and size of the tergal furca, but it also differs in other characters. Echinoderes nybakkeni and E. krishnaswamyi are highly characteristic with their long and flexible lateroventral spines (Higgins 1985, 1986a). Echinoderes nybakkeni is furthermore easily recognized by its prominent pectinate fringe, whereas E. krishnaswamyi has very short and triangular tergal furca. The species $E$. brevicaudatus, E. dujardinii, E. ehlersi and E. imperforatus all have short middorsal spines (>one-half segment length) (Zelinka 1913; Higgins 1966b, 1977a, 1983), contrary to the middorsal spines in E. spinifur$c a$ that are longer than their corresponding segment. Furthermore, E. brevicaudatus has rather short and stubby lateral terminal spines, and is hence easily distinguished from E. spinifurca. Echinoderes ferrugineus, E. pilosus, and E. sublicarum all have rather short tergal furca, that are less than one-half length of the lateral terminal accessory spines (Zelinka 1928, Lang 1949, Higgins 1977b). In E. kozloffi (and in E. 
pilosus) the sternal extensions on segment 13 have setae that extend beyond the tergal furca (Lang 1949, Higgins 1977a). Such setae are not present in E. spinifurca. Echinoderes aureus has a pair of conspicuous subventral scars on segment 3 (Adrianov et al. 2002), and E. pacificus differs from $E$. spinifurca in its relatively short lateral terminal spines (30 percent of trunk length vs. 68 percent of trunk length) (Schmidt 1974, Higgins 1977a). Echinoderes worthingi resembles E. spinifurca but can be distinguished by the obviously shorter tergal furca with serrated inner margins (see Fig. 3; Higgins 1986a) and the relatively short middorsal spines on segments 6 to 9. In $E$. worthingi the middorsal spines are always slightly shorter than their corresponding segment, whereas they are longer than the segment in E. spinifurca. Also see Higgins (1986b) for further notes on the discriminative characters within the above-mentioned species.

Notes on habitat and associated fauna.Echinoderes spinifurca was first found in shell gravel mixed with sand and has later been recorded from more clean shell gravel at a locality nearby (Sørensen, pers. obs.). Other kinorhynchs recorded from both localities were Echinoderes horni Higgins, 1983 and two yet undescribed cyclorhagid taxa. Furthermore, an undescribed species of Zelinkaderes was found in the mixed sediment but not in the clean shell gravel. Echinoderes horni was described from Belize and has been found in coralline mud with Thalasia and fine sediment mixed with sand and shells.

\section{Acknowledgments}

We would like to thank the director and staff at the Smithsonian Marine Station at Fort Pierce for their great hospitality and help during our stay. We also thank Reinhardt M. Kristensen, Jesper Guldberg Hansen and Birna Var Trygvadóttir for help and good company during the stay at the station, and Stine Elle for preparing the line drawings. This work was funded by The Danish Natural Science Research Council (grant no. 51-00-0278) and the Carlsberg Foundation (grant no. ANS-0724/20). This is publication \#616 from the Smithsonian Marine Station at Fort Pierce.

\section{Literature Cited}

Adrianov, A. V. 1989. The first report on Kinorhyncha of the Japanese Sea.-Zoologichesky Zhurnal 61:17-27. [In Russian].

_, \& V. V. Malakhov. 1999. Cephalorhyncha of the World Ocean. KMK Scientific Press Ldt., Moscow, $328 \mathrm{pp}$.

—, C. Murakami, \& Y. Shirayama. 2002. Echinoderes aureus n. sp. (Kinorhyncha: Cyclorhagida) from Tanabe Bay (Honshu Island), Japan with a key to the genus Echinoderes.-Species Diversity 7:47-66.

Bütschli, O. 1876. Untersuchungen über freilebende Nematoden und die Gattung Chaetonotus.Zeitschrift für wissenschaftliche Zoologie 26: 363-413.

Claparède, E. 1863. Beobachtungen über Anatomie und Entwicklungsgeschichte wirbelloser Tiere an der Küste der Normandie angestellt. Wilhelm Engelmann, Lepzig, 120 pp.

Dujardin, F. 1851. Sur un petit animal marin, l'Echinodère, formant un type intermédiaire entre les Crustacés et les Vers.-Annales des Sciences Naturelles, Zoologie, series 3, 15:158160.

Higgins, R. P. 1966a. Echinoderes arlis, a new kinorhynch from the Arctic Ocean.-Pacific Science 20:518-520.

. 1966b. Faunistic studies in the Red Sea (in Winter, 1961-1962), part II. Kinorhynchs from the area of Al-Ghardaqa.-Zoologische Jahrbücher, Systematik, Ökologie und Geographie der Tiere 93:118-126.

- 1977a. Redescription of Echinoderes dujardinii (Kinorhyncha) with descriptions of closely related species.-Smithsonian Contributions to Zoology 248:1-26.

1977b. Two new species of Echinoderes (Kinorhyncha) from South Carolina.-Transactions of the American Microscopical Society 96:340354.

- 1982. Three new species of Kinorhyncha from Bermuda.-Transactions of the American Microscopical Society 101:305-316.

. 1983. The Atlantic barrier reef ecosystem at Carrie Bow Cay, Belize, II: Kinorhyncha.Smithsonian Contributions to the Marine Sciences 18:1-131.

. 1985. The genus Echinoderes (Kinorhyncha: 
Cyclorhagida) from the English Channel.Journal of the Marine Biological Association of the U.K. 65:785-800.

. 1986a. A new species of Echinoderes (Kinorhyncha: Cyclorhagida) from a coarse-sand Californian Beach.-Transactions of the American Microscopical Society 105:266-273.

. 1986b. Redescription of Echinoderes pilosus (Kinorhyncha: Cyclorhagida).-Proceedings of the Biological Society of Washington 99:399405.

, \& R. M. Kristensen. 1988. Kinorhyncha from Disko Island, West Greenland.-Smithsonian Contributions to Zoology 458:1-56.

\& G. C. Rao. 1979. Kinorhynchs from the Andaman Islands.-Zoological Journal of the Linnean Society 67:75-85.

Huys, R., \& A. Coomans. 1989. Echinoderes higginsi sp. n. (Kinorhyncha, Cyclorhagida) from the southern North Sea with a key to the genus Echinoderes Claparède.-Zoologica Scripta 18: 211-221.

Kristensen, R. M., \& R. P. Higgins. 1984. Revision of Styraconyx (Tardigrada: Halechiniscidae), with description of two new species from Disko Bay, West Greenland.-Smithsonian Contributions to Zoology 391:1-40.
Lang, K. 1949. Echinoderida. Pp. 1-22 in N. H. Odhner, ed., Further zoological results of the Swedish Antarctic Expedition 1901-1903, vol. IV No. 2, Norstedt \& Söner, Stockholm.

Schmidt, P. 1974. Interstitielle Fauna von Galapagos, X: Kinorhyncha.-Mikrofauna des Meeresbodens 43:1-15.

Sørensen, M. V., \& R. M. Kristensen. 2000. Marine Rotifera from Ikka Fjord, SW Greenland. With the description of a new species from the rare mineral ikaite.-Meddelelser om Grønland 51: $1-46$.

Southern, R. 1914. Nemathelmia, Kinorhyncha and Chaetognatha.-Proceedings of the Royal Irish Academy 31:1-80.

Zelinka, C. 1896. Demonstration von Tafeln der Echinoderes-Monographie.-Werhandlungen der deutschen zoologischen Gesellschaft 6:197199.

1913. Die Echinoderen der Deutschen Südpolar-Expedition 1901-1903.-Deutsche Südpolar-Expedition 14:419-436.

. 1928. Monographie der Echinodera. Wilhelm Engelmann, Lepzig, 396 pp.

Associate Editor: Stephen L. Gardiner 